\title{
Impact of Exchange Rate Volatility on Afghanistan Trade Flows
}

\author{
M Jawad Shahab*, Amirhamza Aslami, Jawed Ahmad Shahidi \\ Afghanistan
}

*Corresponding Author: M Jawad Shahab, Afghanistan

\begin{abstract}
This study examines the impact of exchange rate volatility on Afghanistan'sexport flows to major trade partner countries from 2006 to 2017. This study uses the ARCH and GARCH model family to examine the conditional variance of the exchange rates, using data from 2006 to 2017. the Fixed Effect (FE) and Random Effect (RE) methods are used to estimate the coefficients of the bilateral exchange rate and to consider heterogeneity and individuality among selected countries. The result indicates that a one percent depreciation of the exchange rate is associated with a 0.6316 percent increase in the exports, holding all other variables constant. If we control the market sizes (GDPs) of export origin and destination countries, the impact of the exchange rate increases to 0.763 percent. Hence, it implies that after controlling for the GDP of Afghanistan and exported countries, one percent depreciation of the exchange rate, on average, is associated with a 0.763 percent increase in the exports. The coefficient of the model is significant at the 0.05 level.
\end{abstract}

\section{INTRODUCTION}

The exchange rate is considered as one of the important indicators of international economic development and thereby has had a significant influence on the country's' foreign tradeflows. Real exchange rate movement is commonly believed to permanently affect both the export and import. One of the major economic issues that have received a great deal of attention by many researchers and academics is also the effects of exchange rate movement on the trade volumes and flows.

There are several empirical works of literature using different measures of exchange rate movement to examine the effect of the exchange rate on the trade flows in both developed and developing countries. Although most evidence argues that the exchange rate movement increases uncertainty and risk and therefore depresses the trade flows, but some other studies suggest otherwise. The widespread popular perception that greater exchange rate risk reduces the trade has helped motivate monetary unification in countries (EU Commission 1990) and is strongly related to currency market intervention by central banks (Bayoumi and Eichengreen 1998). Yet a vast economic literature yields highly inconsistent theoretical and empirical results on this issue. In developing countries due to the lack of good quality data and less developed financial markets, the cost of adjusting to macroeconomic changes is higher compared to those in developed countries. Therefore, one can conclude that the exchange rate movement may have a major impact on the country's trade flows.

In Afghanistan, because of the non-existence of exchange rate policy, the movement of the exchange rate is unpredictable but has practiced mostly increasing and this is likely to cause the tradersto overestimate the exchange rate movement and so the price of both export and import items aremostly increasing. As for Afghanistan's trade is highly unbalanced with more than $90 \%$ imports against less than $10 \%$ exports, so the study of exchange rate movement and its impact on the export side of the trade is taking to be highly prioritized and important.Afghanistan, due to having no systematic and upto-date data in both exchange rate and trade, is always facing the question that what factors are mostly affecting macro and microeconomics changes and gaps, especially in international trade affairs. At least in the last 15 years, Afghanistan even with having the high opportunity of international trade integration and development could not bring a considerable improvement in its international trade especially the export volume. It is proved by empirical studies that the exchange rate is always affecting over all the trade and specifically the export but the level of impact may differ from one country to another.

Afghanistan as a developing country due to having no international trade policy and even strategy and also lack of monetary and exchange policy, is still facing numerous problemsthat make trade 
specifically export unexpanded. This in turn, negatively affects the GDP and economic welfare respectively. Exploring the importance and relationships between export and exchange rate for sure will makes related authorities understand the importance and ensure their commitment to making a comprehensive policy of the exchange rate and also export development. There is still no research available to examine the effect of overall factors especially exchange rate volatility on Afghanistan trade flows, therefore, this study tries to address this gap and assess the effect of the exchange rate on Afghanistan trade flows.

The objective of this paper is to investigate the effect of exchange rate movement on export flows between Afghanistan and other leading trade partners from2006 to 2017. The countries are selected from various regions to capture the varying impact of the exchange rate on the level and degree of export from Afghanistan.

\section{LITERATURE REVIEW}

The exchange rate as an essential factor affecting international trade is started being inthe concentration of macroeconomics literatureafter the Bretton Woods system collapsed(Sugiharti, Esquivias, \& Setyorani, 2020)in both theory and empirical studies ${ }^{1}$. A large body of empirical research illustrates the impact of exchange rate volatility on trade flows either in positive or negative directions based on the assumptions made with respect to the risk preferences, the availability of capital market, the time horizon of trade transactions, and the exchange regime flexibility (Ethier, 1973; Hooper\& Kohlhagen, 1978; De Grauwe, 1988; Franke, 1991; Viaene\& de Vries, 1992; and Sercu\&Vanhulle, 1992). Although, academic literature neither theoretically nor empirically The majority of the studies are focusing on the directions and channels through which the exchange rate movement could affect the real economy, especially the trade flows. There is a wide range of empirical studies illustrating a robust negative relationship between exchange rate movement and trade, while some others did vice versa.Some other empirical studies didn't find a significant relationship between exchange rate volatility and trade flows especially export and argue that because empirical results are very sensitive with some factors such as the model used in the analysis, proxies for the exchange rate(Jantarakolica \& Chalermsook, 2012). Although, the study on the impact of exchange rate volatility on trade flows especially export are mostly obtained in developed countries and it is significantly limited in transition and developing countries (Bakhromov \& Head, 2011) but increasing focus on regional economic integration and accelerating trade volume among different geoeconomic zones especially developing countries encouraged further study on exchange rate volatility and trade relationship. Some empirical studiesin developing countries show that the impact of exchange rate movement on export growth is inconclusive, because of variation in exchange rate policies and level of economic growth (Bahmani-Oskooee , 1986; Coes ,1981; and Rana, 1983). The same result are seen in developed countries, for instance Caglayan and Di (2010) examined the effect of real exchange rate volatility and sectoral trade between the United States and its top thirteen trading partners and found that exchange rate volatility does not systematically affect sectoral trade flows. They argue that any negative effects of exchange rate volatility often tend to be offset by opposite impacts of income volatility. Economic theories also propose the negative association between exchange rate volatility and trade flows as change in exchange rates are linked to uncertainty, cause change in price expectations and change in demand recpectively (Clark,1973; Clark et all., 2004).In developing countries exchange rate volatility along with the financial stability can affect positively or negatively the export in the short or long run. Many research in developing countries show a significan negative relationship between exchange rate volatility and trade flews particularly export. For example, an empirical study from (Hayakawa \& Kimura, 2009) investigated the impact of exchange rate volatility on international trade in East Asian countries comparing the tariff and distance related to the cost of the trade goods. They found that overall exchange rate volatility discourages trade in East Asian countries especially intermediate goods which are more sensitive in international trade. The study also shows that theeffect is more serious in intra-East Asian countries' trade than the trade with other regions. They further add that the negative effect of volatility is greater than the effect of tariffs and smaller than the effect of distance-related costs in East Asian countries.

\footnotetext{
${ }^{1}$ The collapse of Bretton Wood system of fixed exchange rates was one of the most major economic events happened in 1971 as per claim of United State in IMF. For more details refer to (Middleton, Bordo, \& Eichengreen, 1994).
} 
Also, results from Mustafa \& Nishat (2005) in Pakistan indicates that the volatility of the exchange rate has negative and significant effects on export both in the long run and short run with major trade partners considering the aggregated and bilateral trade flows. This result is also seen within disaggregated and particular export and import commodities between Pakistan and Japan from 1980 to 2014 both in the long-run and short-run. Out of 44 exports and 60 import commodities analyzed in this study, seven Pakistan's export commodities to Japan and 12 Pakistan's import commodities from Japan have been affected by exchange rate volatility in the long run and the rest of them were not affected. In the short run, even less number of both export and import have been affected by exchange rate volatility, which the main reason suspected by the study is because most of the trade between Pakistan and Japan is financed by the US dollar so the rupee-yen exchange rate and its volatility is not involved in the picture (Bahmani-Oskooee, Iqbal, \& Salam, 2016). The same study is obtained by (Bahmani-Oskooee \& Gelan, 2018) about twelve African countries considering both the long-run and short-run trade flows. The study finds that in long run both export and import were affected by exchange rate volatility in most of the countries placed in the sample but in the long run, only five countries' exports and one country's imports have been affected by exchange rate volatility. The study argues domestic income as the main determinant of African countries' import and the findings suffering from the aggregated commodities'bais.

Another study from (Hooy \& Choong, 2010) examining the impact of currency volatility on export demand among the South Asian Association for Regional Cooperation (SAARC)countries shows a significant negative result. This study covered Bangladesh, India, Pakistan, and Sri Lanka as the SAARC members, and other members including Afghanistan as the last member of SAARC is excluded in this study ${ }^{2}$.The same study by Bakhromov (2011) indicates that increases in the volatility of the real exchange rate have significant negative effects on equations of exports and imports in the long-run dynamics in Uzbekistan.

Whatever the level of effect of exchange rate volatility on exports differs among commodities and depends on many factors including the degree of risk insalubrity and risk exposure of exporters, the degree of competition, types, and price sensitivity of commodity but overall the effect is undeniable wither positive or negatively. For instance, textile and garment product which have high competition in the global market are more affected by both the exchange rate volatility and export price (Kadir et al., 2011; Jantarakolica \& Chalermsook, 2012). It also depends on the model specification. Many studies use the ARCH and GARCH models either in univariate or bivariate or both methods. Some studies argue that the bivariate method is the most appropriate method to determine the exchange rate volatility (Jantarakolica \& Chalermsook, 2012)while some other studies did not find a significant relationship using other models.

By summarizing the theoretical and empirical studies reviewed above, it can be concluded that high movement in the exchange rate system may have a substantial impact on trade and it may reduceforeign tradeoperations in the export of the countries in accordance to many studies although some other studies do not significantly find the relationship between exchange rate volatility and trade flows.

The research is expected to point out very clearly the level of the exchange rate's effect on the export in Afghanistanin a period which probably will flue within this period. Looking at the literature there is mostly a relationship seen between exchange volatility and export either positively or negatively. Therefore considering the exchange rate movement in Afghanistan with no export development at least for the last 15 years, the expectation from this research goes to the same result from many developing countries which are proving the negative relationship between the exchange rate volatility and export.

\section{RESEARCH METHODOLOGY}

Investigating the impact of exchange rate movement on the export volume, it looks proper to use the trade equation, specifically the export demand function which shows the linkage between export and

\footnotetext{
2 South Asian Association for Regional Cooperation (SAARC) as a platform for economic cooperation is stablished in December 1985 and Afghanistan has received the SAARC membership on 2007. Currently countries such as Afghanistan, Bangladesh, Bhutan, India, Maldive, Nepal, Pakistan, and Sri Lanka are the SAARC members.
} 
factors affecting export, where the one most important is the exchange ratein accordance with the literature.

To achieve the relationship and the impact of the exchange rate on export in Afghanistan, this research obtained secondary data from available related resources. Quantitative methods are used to examine the relationship between nominated variables with the primary goal being to analyze through statistical analysis. Data for all variables are yearly observations spanning the period from 2006 to 2018. The focus is on country-based analysis, in which Afghanistan's total real export to the countries which are major trade partners. All data on exports are obtained from the government departments and international organizations and data for the exchange rate are taken from Afghanistan Central Bank. Data is collected through, Databases and Official journals. Statistical software SPSS and methods are used to analyze the relationship between variables. We further used the Autoregressive Conditional Heteroskedasticity ( $\mathrm{ARCH}$ ) family of models to examinethe conditional variance of the exchange rate itself.

\subsection{Modeling the Exchange Rate Volatility}

Before examining the relationship betweenthe exchange rate and export, we first want to focus on the modeling of the behavior of the conditional variance of the exchange rate itself. This behavior can be examined using the Autoregressive Conditional Heteroskedasticity (ARCH) family of models. ARCH was initially developed by Robert F. Engle in his seminar paper 'Autoregressive Conditional Heteroskedasticity with Estimates of the Variance of United Kingdom Inflation' published in Econometrica in 1982, and which began a whole new era in applied econometrics with many ARCH variations, extensions, and applications.

Using the daily exchange rate USD and Afghani (a five-day week from July 2006 to July 2019) which is consists of 3397 observations. Equation (1) is estimated to test for the ARCH effect.

$$
\text { Exchange }_{t}=\infty+\beta \text { exchang }_{t-1}+\epsilon_{t}
$$

Where Exchange Ex $_{t}$ is the daily exchange of Afghani US dollars, exchange $e_{t-1}$ is the exchange rate of the previous day, $\infty$ and $\beta$ are parameters, and $\epsilon_{t}$ is the error term in time t. Based on the results of equation (1), the ARCH test is presented in table 1. The results confirm the ARCH effect on the exchange rate.

Table1. ARCH Modle

\begin{tabular}{|c|c|c|c|c|}
\hline \multicolumn{5}{|c|}{ Heteroskedasticity Test: ARCH } \\
\hline F-statistic & 243.1366 & \multicolumn{2}{|c|}{ Prob. F(1,3379) } & 0.0000 \\
\hline Obs*R-squared & 226.9503 & \multicolumn{2}{|c|}{ Prob. Chi-Square(1) } & 0.0000 \\
\hline \multicolumn{5}{|c|}{ Test Equation: } \\
\hline \multicolumn{5}{|c|}{ Dependent Variable: RESID ${ }^{\wedge} 2$} \\
\hline \multicolumn{5}{|c|}{ Method: Least Squares } \\
\hline \multicolumn{5}{|c|}{ Date: $12 / 17 / 19$ Time: 01:40 } \\
\hline \multicolumn{5}{|c|}{ Sample (adjusted): 7/25/2006 7/09/2019 } \\
\hline \multicolumn{5}{|c|}{ Included observations: 3381 after adjustments } \\
\hline Variable & Coefficient & Std. Error & t-Statistic & Prob. \\
\hline $\mathrm{C}$ & 0.045289 & 0.005849 & 7.743127 & 0.0000 \\
\hline $\operatorname{RESID}^{\wedge} 2(-1)$ & 0.259084 & 0.016616 & 15.59284 & 0.0000 \\
\hline R-squared & 0.067125 & \multicolumn{2}{|c|}{ Mean dependent var } & 0.061120 \\
\hline Adjusted R-squared & 0.066849 & \multicolumn{2}{|c|}{ S.D. dependent var } & 0.346719 \\
\hline S.E. of regression & 0.334930 & \multicolumn{2}{|c|}{ Akaike info criterion } & 0.650801 \\
\hline Sum squared resid & 379.0499 & \multicolumn{2}{|c|}{ Schwarz criterion } & 0.654425 \\
\hline Log-likelihood & -1098.180 & \multicolumn{2}{|c|}{ Hannan-Quinn criterion. } & 0.652097 \\
\hline F-statistic & 243.1366 & \multirow{2}{*}{\multicolumn{2}{|c|}{ Durbin-Watson stat }} & 2.038556 \\
\hline Prob(F-statistic) & 0.000000 & & & \\
\hline
\end{tabular}




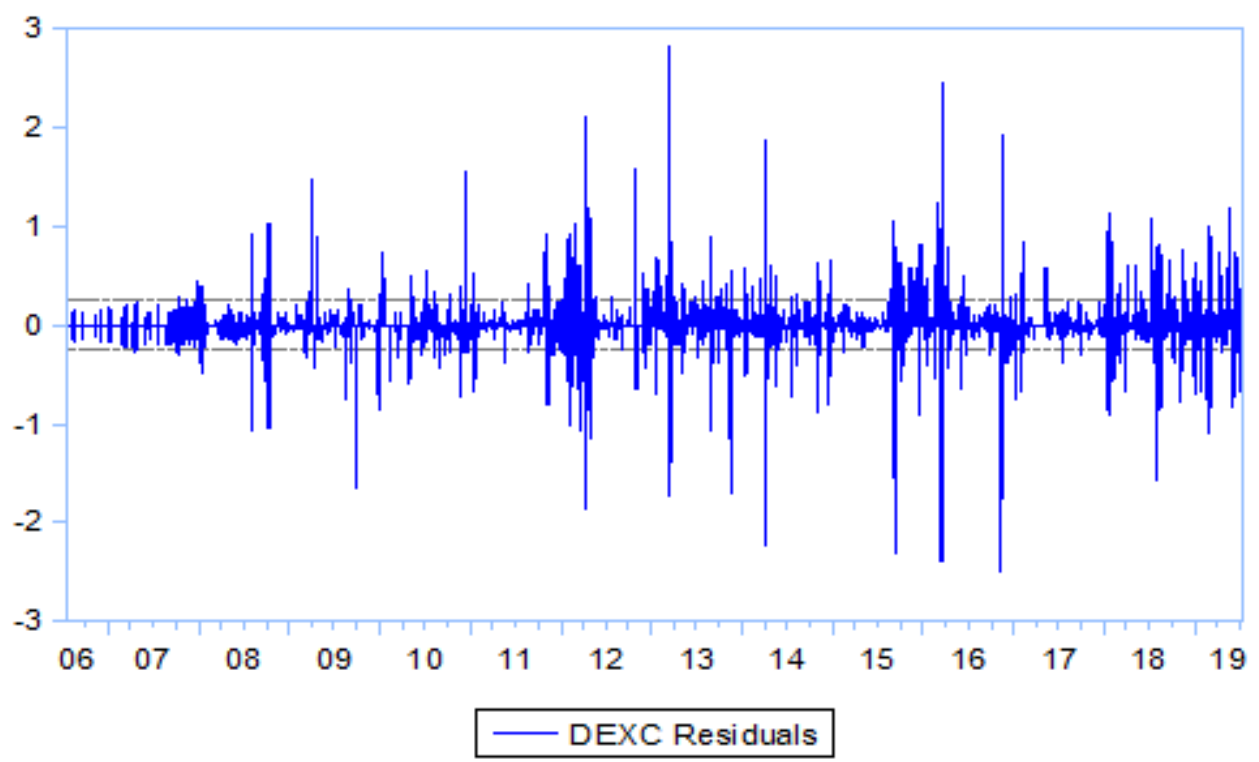

The results of table 1 confirm the ARCH effect and also graph 1 also show that low volatility of exchange rate is followed by low volatilities (calm period) and higher volatility is further followed with higher variance. Given that, we can model exchanger rate volatility as follows:

$$
\begin{gathered}
\text { Exch ange }_{t}=\infty+\beta \text { exchange } \text { ex-1 }_{t}+\epsilon_{t}(2) \\
\epsilon_{t} \mid \Omega_{t} \sim \text { iid } N\left(0, h_{t}\right) \\
h_{t}=\gamma_{0}+\sum_{j=1}^{q} \gamma_{j} \varepsilon_{t-j}^{2}
\end{gathered}
$$

Where equation (2) shows the mean model and equation (3) shows the variance model. $h_{t}$ is variance of exchange rate at time $t, \varepsilon_{t-j}^{2}$ is square of residual from equation (2) at time $t-j$. The problem with the estimation of equations (2) and (3) is that in the $\mathrm{ARCH}(\mathrm{q})$ model it happens that coefficients are negative which is not logical since variances are all positive. To address this issue we will extend our model Generalized Autoregressive Conditional Heteroskedasticity (GARCH). $\operatorname{GARCH}(\mathrm{p}, \mathrm{q})$ model is specified as follows:

$$
\begin{array}{r}
\text { Exchange }_{t}=\infty+\text { exchange }_{t-1}+\epsilon_{t}(4) \\
\epsilon_{t} \mid \Omega_{t} \sim{\text { iid N }\left(0, h_{t}\right)}^{q} \\
h_{t}=\gamma_{0}+\sum_{i=1}^{p} \delta_{j} h_{t-i}+\sum_{j=1}^{q} \gamma_{j} \varepsilon_{t-j}^{2}
\end{array}
$$

Model (4) and (5) says that the value of the variance scaling parameter of the exchange rate $h_{t}$ now depends both on the past values of the exchange shocks, which are captured by the lagged squared residual terms, and on past values of itself, which are captured by lagged $h_{t}$ terms. A major restriction of the equation (3) and (5) is their symmetric specification. It means that what matters is only the absolute value of the innovation and not is the direction (because the residual term is squared). Therefore, equation (3) and (5) assumes that a large positive shock in the exchange rate will have the same effect on the volatility of the series as a large negative shock of the same magnitude. However, empirical results show that negative shocks "bad news" in the market have a large impact on the volatility of the exchange rate than do positive shocks "good news" of the same magnitude. The specification for the threshold GARCH (TARCH) model is given by:

$$
\begin{array}{r}
\text { Exchange }_{t}=\infty+\text { Bexchange }_{t-1}+\epsilon_{t}(6) \\
\epsilon_{t} \mid \Omega_{t} \sim{\text { iid } N\left(0, h_{t}\right)}^{p} h_{t}=\gamma_{0}+\sum_{i=1}^{p} \delta_{j} h_{t-i}+\sum_{i=1}^{p} \theta_{t} d_{t-i} \varepsilon_{t-i}^{2}+\sum_{j=1}^{q} \gamma_{j} \varepsilon_{t-j}^{2}
\end{array}
$$

Where $d_{t-i} \varepsilon_{t-i}^{2}$ is a dummy interaction that takes $d_{t-i}$ takes 1 for negative shocks and 0 otherwise. Equation (7) will enable us to not only model the volatility of the exchange rate but also will enable us to test the difference in the impact of the positive and negative exchange rate shocks.

The results of equation (7) are reported in table 2. The results show that the one-period pas exchange rate significantly determines the exchange rate. Apart from the third log of residual squared term, 
which is also holding a negative sign, all residuals square terms are statistically significant at the 0.01 level. Moreover, all GARCH terms are highly significant, which confirms the cluster volatility assumption also in the exchange rate as well.

Table2. Threshold GARCH $(5,6)$

\begin{tabular}{|c|c|c|c|c|}
\hline \multicolumn{5}{|c|}{$\begin{array}{l}\text { Dependent Variable: EXCHANGE } \\
\text { Method: ML ARCH - Normal distributi }\end{array}$} \\
\hline \multicolumn{5}{|c|}{ Date: $12 / 17 / 19$ Time: $15: 34$} \\
\hline \multicolumn{5}{|c|}{ Sample (adjusted): 7/24/2006 7/09/2019 } \\
\hline \multicolumn{5}{|c|}{ Included observations: 3382 after adjustments } \\
\hline \multicolumn{5}{|c|}{ Failure to improve likelihood (non-zero gradients) after 31 iterations } \\
\hline \multicolumn{5}{|c|}{ Coefficient covariance computed using the outer product of gradients } \\
\hline \multicolumn{5}{|c|}{ Presample variance: backcast (parameter $=0.7$ ) } \\
\hline Variable & Coefficient & Std. Error & z-Statistic & Prob. \\
\hline $\mathrm{C}$ & -0.032593 & 0.011698 & -2.786257 & 0.0053 \\
\hline EXCHANGE(-1) & 1.000689 & 0.000194 & 5148.219 & 0.0000 \\
\hline \multicolumn{5}{|l|}{ Variance Equation } \\
\hline $\mathrm{C}$ & 0.008996 & 0.000372 & 24.19842 & 0.0000 \\
\hline $\operatorname{RESID}(-1)^{\wedge} 2$ & 0.208158 & 0.021706 & 9.590056 & 0.0000 \\
\hline $\operatorname{RESID}(-1)^{\wedge} 2 *(\operatorname{RESI}$ & 0.217745 & 0.032402 & 6.720157 & 0.0000 \\
\hline $\operatorname{RESID}(-2)^{\wedge} 2$ & 0.209510 & 0.019050 & 10.99791 & 0.0000 \\
\hline $\operatorname{RESID}(-3)^{\wedge} 2$ & -0.020225 & 0.018665 & -1.083541 & 0.2786 \\
\hline $\operatorname{RESID}(-4)^{\wedge} 2$ & 0.225534 & 0.015894 & 14.18970 & 0.0000 \\
\hline GARCH(-1) & 0.339755 & 0.045172 & 7.521370 & 0.0000 \\
\hline GARCH (-2) & -0.069454 & 0.029278 & -2.372237 & 0.0177 \\
\hline GARCH(-3) & 0.069766 & 0.020957 & 3.329014 & 0.0009 \\
\hline GARCH(-4) & 0.097518 & 0.020851 & 4.676911 & 0.0000 \\
\hline GARCH(-5) & -0.109117 & 0.001383 & -78.91064 & 0.0000 \\
\hline GARCH(-6) & 0.040825 & 0.010124 & 4.032496 & 0.0001 \\
\hline R-squared & 0.999309 & \multicolumn{2}{|c|}{ Mean dependent var } & 56.56399 \\
\hline Adjusted R-squared & 0.999309 & \multicolumn{2}{|c|}{ S.D. dependent var } & 9.407669 \\
\hline S.E. of regression & 0.247282 & \multicolumn{2}{|c|}{ Akaike info criterion } & -0.503880 \\
\hline Sum squared resid & 206.6818 & \multicolumn{2}{|c|}{ Schwarz criterion } & -0.478520 \\
\hline Log-likelihood & 866.0612 & \multicolumn{3}{|c|}{ Hannan-Quinn criterion. -0.494814 } \\
\hline Durbin-Watson stat & 2.333037 & & & \\
\hline
\end{tabular}

The estimated coefficient of the dummy interaction (threshold) is positive and statistically very significant. it shows that there are asymmetries in the impact of shocks. Specifically, negative shocks (bad news) have larger effects on the volatility of the exchange rate than positive shocks (good news).

\subsection{Empirical Model}

To examine the impact of the bilateral exchange rate on the export of Afghanistan during 2006-2017, we developed three different models. Equation (1) will enable us to test the impact of the bilateral exchange rate on the volume of export of Afghanistan, considering that all other variables are constant. (1)

Where $\operatorname{Ln}\left(E X P_{i j, t}\right)$ is the logarithm of export of Afghanistan to country $j$ at time $t$, $\ln \left(\right.$ exc $\left.h_{i j t}\right)$ is the logarithm of the bilateral exchange rate of Afghani to exporting country $j$ at time $t, u_{i t}$ is the error term at time t, and $\beta_{0}$ and $\beta_{1}$ are coefficients. To control for the GDP of Afghanistan and its partner country equation (2) is developed.

$\operatorname{Ln}\left(E X P_{i j, t}\right)=\beta_{0}+\beta_{1} \ln \left(\operatorname{lexch}_{i j t}\right)+\beta_{2} \ln \left(\lg \lg _{i t}\right)+\beta_{2} \ln \left(l G D P_{j t}\right)+u_{i t}$

Where $\ln \left(l G D P_{i t}\right)$ is the logarithm of Afghanistan's GDP and $\ln \left(l G D P_{j t}\right)$ is the logarithm of the GDP of the $j$ th exported country at time t. Also, equation (2) is extended by controlling the distance between Afghanistan and export destination and economic similarities:

$\operatorname{Ln}\left(E X P_{i j, t}\right)=\beta_{0}+\beta_{1} \ln \left(\operatorname{lexch}_{i j t}\right)+\beta_{2} \ln \left(\lg P_{i t}\right)+\beta_{2} \ln \left(l G D P_{j t}\right)++\beta_{3} \ln \left(\right.$ dist $\left._{i j}\right)+$ $\beta_{4} \operatorname{Linder}_{i j}+u_{i t}$

Where $\ln \left(\right.$ dist $\left._{i j}\right)$ is the logarithm of the distance between Afghanistan and export destination and Linder is the economic similarity between country $i$ and $\mathrm{j}$. Linder is calculated as follows: 
lLinder $_{i j t}=\operatorname{Ln}\left(p c i_{i}-p c i_{j}\right)^{2}$

Where $p c i_{i}$ is per capita income in the country $i$, and $p c i_{j}$ is the per capita income of country $j$. Furthermore, equation (3) further extended to control for the adjacency (border) and sharing a common language:

$$
\begin{aligned}
& \operatorname{Ln}\left(E X P_{i j, t}\right)=\beta_{0}+\beta_{1} \ln \left(\operatorname{lexch}_{i j t}\right)+\beta_{2} \ln \left(\operatorname{lGDP} P_{i t}\right)+\beta_{2} \ln \left(\operatorname{lGDP}_{j t}\right)++\beta_{3} \ln \left(\text { dist }_{i j}\right)+ \\
& \beta_{4} \text { Linder }_{i j}+\beta_{5} \text { Border }_{i j}+\beta_{6} \text { Lang }_{i j}+u_{i t}
\end{aligned}
$$

Different sources are utilized to collect data to estimate the above models. Annual data on bilateral exports of Afghanistan with its main trading partners (17 countries) have been collected from the UNCTAD and COMTRADE databases, data about GDP and GCP per capita are retrieved from the World Bank's World Development Indicators (WDI). The bilateral exchange rate is collected from the ministry of finance of Afghanistan and data regarding distance, border, and language are retrieved from the CEPII database.

Given the nature of the data structure, the Fixed Effect (FE) method will be used to estimate equation (1) and (2). To consider heterogeneity and individuality among selected countries, and provided that equations (3) and (5) include some time-invariant variables there for it will be estimated by the Random Effect method (RE).

Figure2. The Exchange rate of USD to Afghani During 2010 and 2019.

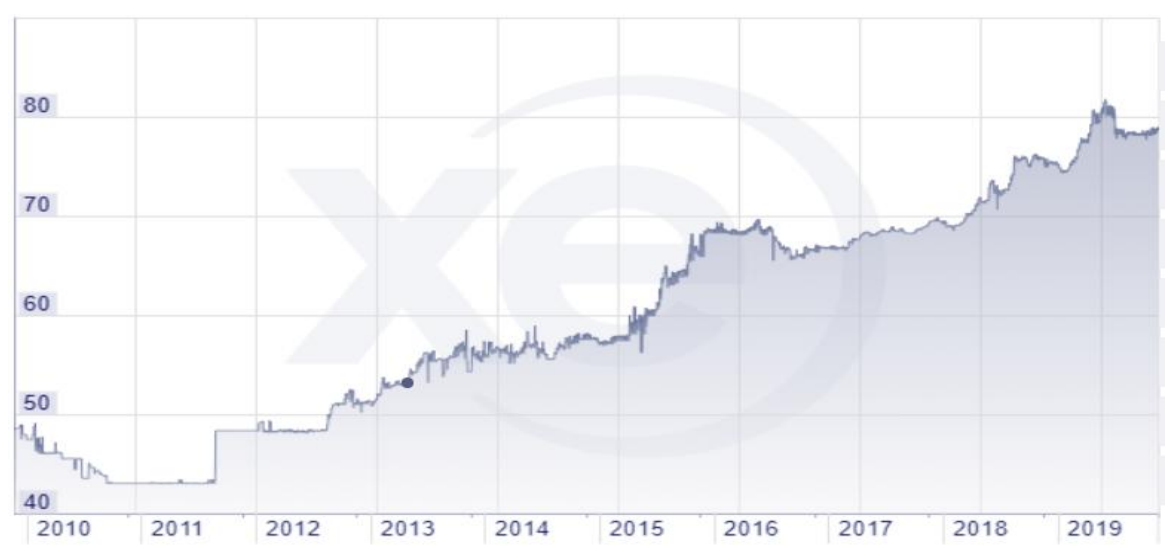

\section{RESULT}

The results of the random effect and fixed-effect models are presented in Table 3. Model 1 and 2 are estimated using the fixed-effect model after performing the Hausman test. Since model 3 and 4 include time-invariant variables, are estimated using a random-effect model. The goodness-of-fit of the first two models are 82.6 and 83.4 percent, while it is 14.2 and 18.6 percent for models 3 and 4 , respectively. All models include 176 observation (17 crosssection, and 12 years). The estimated results of the model indicate that the majority of the coefficients hold the expected signs. The residuals of the model are also normally distributed and hence, the modelsare not suffering from serial correlation as well. Therefore, we can conclude that our model is well-behaving.

Table3. Estimated Results of the Random Effect and Random Effect Models for the 2006-17 period (Dep. Variable $=$ Logarithm of Exports)

\begin{tabular}{|l|l|l|l|l|}
\hline Variable & Model 1 & Model 2 & Model 3* & Model 4* \\
\hline Constant & 0.54826 & -2.35293 & 15.3247 & $(0.0005)$ \\
& $(0.2035)$ & $(0.2928)$ & 0.03865 & 12.5867 \\
& 0.63116 & 0.76246 & $(0.005)$ \\
\hline Ln(Exch) & $(0.0514)$ & $(0.0194)$ & 0.19087 & -0.0034 \\
& & 0.43733 & $(0.4331)$ & $(0.982)$ \\
\hline LnGDP $_{\mathrm{i}}$ & $(0.1508)$ & 1.02140 & 0.19506 \\
& & 0.23904 & $(0.0001)$ & $0.4208)$ \\
\hline LnGDP $_{\mathrm{j}}$ & & $(0.5770)$ & -2.05441 & $(0.0001)$ \\
\hline LnDist & & $(0.0025)$ & -1.75424 \\
& & & -0.29195 & $(0.0052)$ \\
\hline Linder & & & $(0.0133)$ & -0.26367 \\
Coefficient & & & & $(0.0123)$ \\
\hline
\end{tabular}




\begin{tabular}{|l|l|l|l|l|}
\hline Border & & & & -0.01032 \\
& & & & $0.9947)$ \\
\hline Language & & & & 0.91466 \\
& & & $0.4421)$ \\
\hline Observation & $\mathbf{1 7 6}$ & $\mathbf{1 7 6}$ & $\mathbf{1 7 6}$ & $\mathbf{1 7 6}$ \\
\hline R-squared & $\mathbf{0 . 8 2 6}$ & $\mathbf{0 . 8 3 4}$ & $\mathbf{0 . 1 4 2}$ & $\mathbf{0 . 1 8 6}$ \\
\hline F Statistic & $\mathbf{4 4 . 0 2 0}$ & $\mathbf{4 1 . 3 2 0}$ & $\mathbf{5 . 6 5 0}$ & $\mathbf{5 . 4 6 5}$ \\
\hline
\end{tabular}

* Model 3 and 4 are estimated using the Random Effect technique

Note: In parenthesis are the p-value

The estimated coefficients of the bilateral exchange rate apart from model 4are positive and statistically significant. This confirms the gravity assumption of the market size effect on the inflow of bilateral FDI to Afghanistan. The positive sign of the exchange rate implies that a one percent depreciation of the bilateral exchange rate, on average, will have a positive impact on the export's amounts. The coefficient of the exchange rate in model medicate indicates that one percent depreciation of the exchange rate is associated with a 0.6316 percent increase in the exports, holding all other variables constant. If we control the market sizes (GDPs) of export origin and destination countries, the impact of the exchange rate increases to 0.763 percent. Hence, it implies that after controlling for the GDP of Afghanistan and exported countries, one percent depreciation of the exchange rate, on average, is associated with a 0.763 percent increase in the exports. The coefficient of the model is significant at the 0.05 level. The finding is consistent with the empirical and theoretical literature (Sugiharti et al., 2020; Hayakawa \& Kimura, 2009; Mustafa \& Nishat, 2005; )

Besides, if we control for the distance of the export, and economic similarities of the export destination, the impact of the exchange rate drastically decreases and becomes statistically insignificant. The estimated result of model three shows that a one percent depreciation of the exchange rate is associated with a 0.0386 percent increase in the export, which is economically very small and statistically insignificant. Moreover, after controlling the full set of variables (market size, distance, economic similarities, border, and language), the coefficient of the bilateral exchange rate becomes negative. It is not consistent with empirical and theoretical literature, but at best, it is very insignificant.

The findings suggest that the exchange rate has no impact on the flow of exports of Afghanistan during the study period. This is logical since the majority of export items are agricultural and lowvalue goods, which is demand inelastic, and depreciation of the exchange rate does not significantly decrease their values. The major barriers to exports are considered to be processing, packaging, and transportation.

The estimated results of table 3 show that the coefficients of the GDP of Afghanistan are positive but statistically insignificant. It implies that GDP has no impact on the export volume. However, the coefficient of GDP for export destination countries are positive and statistically significant. It implies that Afghanistan, on average, is exporting more to larger economies as compared to the small economies. Figure 3 shows the major export partners of Afghanistan, which Pakistan and India are at the top of major export countries.

Figure3. Afghanistan's major export partners from 2008-2016.

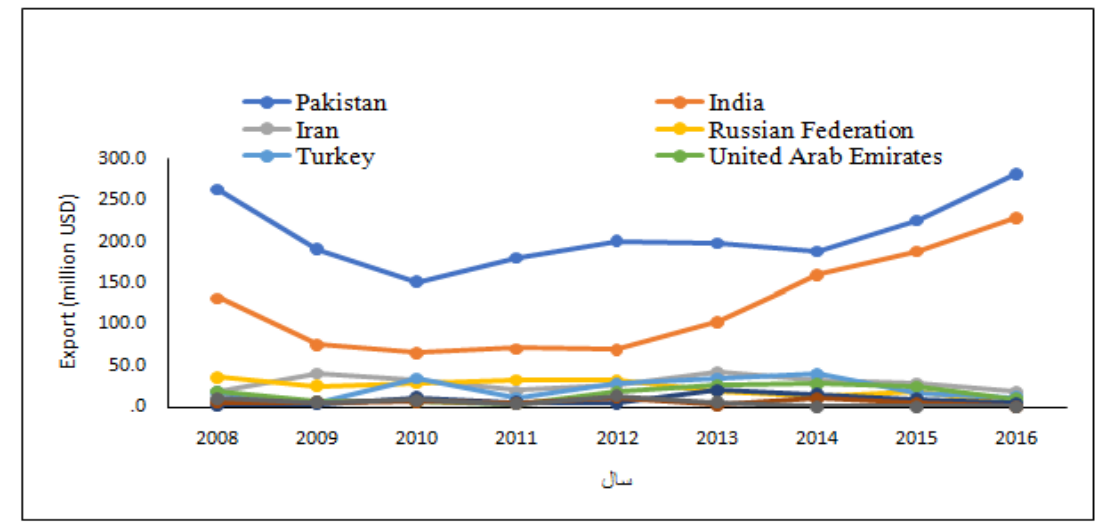

Figure1. Major Export Partners of Afghanistan 
The economic similarity between the two countries can also influence the volume of trade flows into the countries. There are two different theories, Heckscher-Ohlin (1933) and Linder (1961). The first claim that countries with differences tend to do more trade, while the former theory claims that countries with economic similarities tend to do more trade [16]. Therefore, the result is expected, both positive or negative. The estimated coefficient of Linder's is coherent with the Heckscher-Ohlin hypothesis. This means that Afghanistan is exporting more to the countries which are structurally differentfrom Afghanistan. The coefficient is statistically significant at the 0.05 level.

The geographical variables, distance, and sharing borders are vague. The coefficients of distance, as expected, are negative and are coherent with the underlying logic of considering distance as a cost of logistics. This implies that a one percent increase in the distance of the export destination, on average, is associatedwith a 1.754-2.054 percent decrease in the export volume. The coefficient is significant at the 0.05 level. On the other hand, the adjacency effects hypothesis is not supported by the result of the border coefficient. The coefficient is surprisingly negative but economically very small and statistically very insignificant. It shows that there are no differences in the volume of exports to neighboring countries as compared to the rest of the world.

Moreover, language a proxy for the cultural links is holding a positive sign as was expected but statistically very insignificant. Language is a proxy of the cultural aspect of international transactions and is an indicator of ease of doing business across borders. Sharing the common language reduces the costs of trade, and therefore, it was expected that the common language would have a positive effect on the export volume. This means that exportflow from countries that Afghanistan has shared a language does not significantly different as compared with the rest of the world.

\section{CONCLUSION}

The exchange rate as one of the important indicators of economic development is not yet studied to see if its fluctuation and variation affect Afghanistan's trade flows. It is commonly believed that real exchange rate movements permanently affect both the export and import and several empirical literatures using different measures of exchange rate movement to examine the effect of exchange rate on the trade flows in both developed and developing countries.

Because of the non-existence of an exchange rate policy in Afghanistan, the movement of the exchange rate is looked to be unpredictable as there is no research available focusing on this context. On the other hand, as Afghanistan's trade is highly unbalanced with more than $90 \%$ imports against less than $10 \%$ exports, so the study of exchange rate movement and its impact on the export side of the trade is thought to be highly prioritized and important.

Using the daily exchange rate USD and Afghani (a five-day week from July 2006 to July 2019) consists of 3397 observations the estimation confirmed the ARCH effect and show that low volatility of exchange rate is followed by low volatilities (calm period) and higher volatility is further followed with higher variance.

Estimation shows that the coefficients of the bilateral exchange rate are positive and statistically significant. The positive sign of the exchange rate implies that a one percent depreciation of the bilateral exchange rate, on average, will have a positive impact on theexport amounts. The coefficient of the exchange rate in the model indicates that a one percent depreciation of the exchange rate is associated with a 0.6316 percent increase in the exports, holding all other variables constant. If we control the market sizes (GDPs) of Afghanistan and destination countries, the impact of the exchange rate increases to 0.763 percent. The coefficient of the model is significant at the 0.05 level. The finding is consistent with the empirical and theoretical literature (Sugiharti et al., 2020; Hayakawa \& Kimura, 2009; Mustafa \& Nishat, 2005; )

If we control for the distance of the export, and economic similarities of the export destination, the impact of the exchange rate drastically decreases and becomes statistically insignificant. The estimated result of model three shows that a one percent depreciation of the exchange rate is associated with a 0.0386 percent increase in the export. Moreover, after controlling the full set of variables (market size, distance, economic similarities, border, and language), the coefficient of the bilateral exchange rate becomes negative. It is not consistent with empirical and theoretical literature, but at best, it is very insignificant.

The findings suggest that the exchange rate has no impact on the flow of exports of Afghanistan during the study period. This is logical since the majority of export items are agricultural and low- 
value goods, which is demand inelastic, and depreciation of the exchange rate does not significantly decrease their values. The major barriers to exports are considered to be processing, packaging, and transportation. Findings also show that coefficients of the GDP of Afghanistan are positive but statistically insignificant. It means that GDP has no impact on the export volume. It implies that Afghanistan, on average, is exporting more to larger economies as compared to the small economies.

\section{REFERENCES}

[1] Arize, C., Osang, T. and Slottje J. D. (2005), "Exchange-Rate Volatility in Latin America and its Impact on Foreign Trade," available at http://faculty.smu.edu/tosang/pdf/latin.pdf [accessed 24 August 2017]

[2] Bahmani,O, M.,Hegerty, S.W. (2007). "Exchange rate volatility and trade flows: a review article" Journal of Economic Studies, 34(3), pp.211-25

[3] Bakhoromov, Nadir. (2011) The Exchange Rate Volatility and the Trade Balance: Case of Uzbekistan. Journal of Applied Economics and Business Research, 3, pp. 149-161.

[4] Coes, D. (1981), "The Crawling Peg and Exchange Rate Uncertainty," in J. Williamson(ed) New York: SDT. Martin's Press, 113-136.

[5] DeGrauwe, P. (1988), "Exchange Rate Variability and the Slowdown in Growth of International Trade," IMF Staff Papers, 35, 63-84.

[6] Ethier, W. (1973). International trade and the forward exchange market, American Economic Review, 63(3), pp. 494-503

[7] Franke, G. (1991). Exchange rate volatility and international trading strategy, Journal of International Money and Finance, 10(2), pp. 292-307.

[8] Hooper, P., Kohlhagen, S. W. (1978).The Effects of Exchange Rate Uncertainty on the Price and Volume of International Trade. Journal of International Economics, 8, 483-511.

[9] Kadir, A. H., Masinaei, R., Rahmani. N. (2011). Long-Term Effects of Bank Consolidation Program in a Developing Economy, Journal of Asia Pacific Business Innovation and Technology Management.Volume 1, No. 1, P20-30

[10] Khan, A. J, Azim, P., Syed, H. (2014): The Impact of Exchange Rate Volatility on Trade: A Panel Study on Pakistan's Trading Partners. the Lahore Journal of Economics 19, pp. 31-66.

[11] Mustafa, K., \& Nishat, M. (2004).Volatility of exchange rate growth in Pakistan: The structure and interdependent markets. Pakistan Development Review, 43(4), 813-828.

[12] Rana, P. (1983), "The Impact of Generalized Floating on Trade FlowsNeeds, Selected Asian Developing Countries," New York Garland Publishers.

[13] Piet, S., Chyntia, V. (1992). Exchange Rate Volatility, International Trade, and the Value of Exporting Firms. Journal of Banking and Finance. 16: 155-82.

[14] Vianne, J. M. and C. G. de Vries (1992): International Trade and Exchange Rate Volatility. European Economic Review, 36, 1311-1321.

[15] Carmen, S \& Nicolae. G (2011), The Relationship Between Exchange Rate and Exports in Romania, Annales Universitatis Apulensis Series Oeconomica, 13, 1-4.

[16] Penkova.P,(2011).Trade Convergence and Exchange Rate Regime: Evidence from Bulgaria and Romania, BNB, Discussion Papers, no. 85.

Citation: M Jawad Shahab, Amirhamza Aslami, Jawed Ahmad Shahidi. "Impact of Exchange Rate Volatility on Afghanistan Trade Flows" International Journal of Managerial Studies and Research (IJMSR), vol 8, no. 12, 2020, pp. 15-24. doi: https://doi.org/10.20431/2349-0349.0812002.

Copyright: () 2020 Authors. This is an open-access article distributed under the terms of the Creative Commons Attribution License, which permits unrestricted use, distribution, and reproduction in any medium, provided the original author and source are credited. 